\title{
8. The media and leadership: An exploratory study of Howard and Costello
}

\section{ABSTRACI}

This article explores the proposition that the Australian federal Press Gallery operates as a pack and, as such, engages in feeding frenzies when presented with a major story. It uses framing analysis to argue that while the gallery can act as a Pack, even when the journalists have to work independently to obtain the background needed for a story, this does not mean that a feeding frenzy takes place. In fact it argues that Gallery journalists can act as 'wise heads' and potentially calm an issue down, rather than beat it up for their own purposes.

Keywords: framing analysis; gatekeeping; journalist-source relationships; political journalism; press gallery

\section{STEPHEN TANNER}

\section{University of Wollongong}

\section{Introduction}

A GREAT deal has been written about the propensity of press gallery journalists to work in packs (Sabato, 1991; Simons, 1999; Tanner 1999; Wilmoth, 1994; Economou and Tanner, 2008). In at least one manifestation, the pack argument also holds that journalists not only move together, conducting interviews in groups-a tendency which means that they receive the same information from the same group of sources-but also respond as one to stories, including the way they write them up. Taking this approach, Sabato (1991) has likened journalists working on a major story to a shark feeding frenzy or even a dog pack, analogies that have been picked up by later writers. However, the parameters within which individual journalists operate can be influenced by a range of factors, including organisational pressures to perform, their own aspirations, and, 
of course, the group dynamics that influence how the 'pack' operates. At both an individual and pack level, journalists and the media organisations have considerable capacity to shape the way in which the issue is presented.

Individually, journalists make a number of judgments, starting with which stories are newsworthy. This is the gatekeeping process identified by White (1950). This takes place at various steps in the editorial process (see Tanner, 1999, pp. 79-81). However, the individual journalist can also influence the way in which the issue is presented through: (a) the selection of sources; (b) the amount of space allocated to particular sources; (c) the placement of those comments within the story; and (d) the language employed to present an issue or even one side of an issue.

At an institutional level, the capacity of the media organisation to shape the way in which an issue is presented is further enhanced. For example, while an individual journalist may have a particular view of how a story should be presented, including slanting the presentation to favour a particular side, this can be overturned at other points in the editorial process (although is less likely to happen to copy produced by senior journalists than it is to the work of junior reporters). Further, the decision as to where the story is placed (for example, one of the major news pages as opposed to a spill page deeper in the paper) is rarely made by the reporter who writes the story, although their seniority can influence its placement. Their seniority within the organisation can also influence the public's reaction to the story.

Journalist-source relationships are particularly important in the development of political stories. As the case study will reveal, it is far more difficult for a pack to operate in a situation whereby information is not being provided in formal press conference situations where journalists have the opportunity to feed off each other and question individuals in an open forum. As the case study is expected to show, much of the information upon which journalists relied in reporting on and analysing this story was provided by sources who wished to retain their anonymity, particularly during the developmental phase of the issue when the outcomes were unknown and they were seeking to protect their own political hides. It is more likely that such information was provided during one-on-one telephone calls, or individual face-to-face conversations, rather than in a public forum in which the source's identity is more vulnerable to public revelation. 


\section{Framing a story}

Media organisations have considerable capacity to determine how an issue is presented to the public. Potentially, this also means that the media can influence how audiences interpret events. Over the years a number of theories have been posited to explain media effects, ranging from minimal effects to powerful effects and, more recently somewhere in between (see Ward, 1995; McCombs, 2005). Recently, explanations based around the notion of framing, a concept attributed to Goffman (1974), but also promoted by the likes of Tuchman (1978), have gained popularity among some scholars.

According to Tankard et al (1991) framing is 'the central organising idea for news content that supplies a context and suggests what the issue is through the use of selection, emphasis, exclusion, and elaboration' (cited in McCombs and Ghanem, 2001, p. 70). The media influences which issues we believe are important by a number of ways: 1 . by focusing on some issues and ignoring others; or 2. by featuring some issues more prominently than others. Consequently, over time we build up an image of which issues are important and those which are not. According to Druckman (2001): 'framing effects work through a psychological process in which individuals consciously and deliberately think about the relative importance of different considerations suggested by a frame' (p. 1043). They do this by altering belief importance (Nelson \& Oxley, 1999). The latter argue that:

while issue frames may affect the content of one's beliefs, they also affect the importance individuals attach to particular beliefs. This is an essential distinction between framing and other forms of communication-based attitude change (p. 1041).

Druckman believes that framing effects are linked to source credibility. This may be defined a number of ways, including through 'public approval, likeability [and] ideology' (p. 1045). Drawing on the work of Lupia (2000), Druckman argues that credibility is based on two elements: 1. the speaker must be regarded by their target audience as having the knowledge required to speak or write authoritatively about the topic in question; and 2. the audience trusts the speaker to reveal what he or she knows about the story (p. 1061).

From the perspective of this article, it is important to point out that framing occurs at a number of levels, including at the level of the individual 
actors in a story, and also in terms of the way in which the reporter or media organisation responds to and reports on the issue. In the case of political issues, each of the sources quoted will frame their argument in a way that suits their purposes. That is, they will seek to put the most favourable 'spin' on an issue (positive or negative, depending on their objectives). All political actors hope that journalists will accept their frame or spin and ignore or play down the perspective favoured by their political opponents. The reporters and media organisations will likewise frame the issues according to a range of criteria, including newsworthiness and news values, ethical concerns, questions of taste, personal preferences and perhaps even political considerations.

\section{The case study}

This study will use framing to analyse media coverage of a still-born leadership clash between John Winston Howard, Prime Minister of Australia between 1996 and 2007, and his deputy and Treasurer during that same period, Peter Costello. Speculation about the prospect of a clash surfaced in September 2007, just two months out from the federal election which saw Howard's liberal-National Party coalition government defeated in a landslide to Labor. Howard suffered the double ignominy of also losing his seat in the House of Representatives, just the second prime minister in Australian political history to suffer such a fate.

The two men had a history of discord, despite their close working relationship, which was built in part on Costello's belief that they had an agreement the Prime Minister would step down during his second term, thereby paving the way for the then Treasurer to achieve his political ambitions. In fact there had been a number of occasions during the 11 years the government was in office when a challenge appeared likely. However, on all occasions the Prime Minister stared down his challenger.

On all occasions the challenge-or even simply the prospect thereof-was covered in depth by the media. This is not surprising, given that leadership challenges, particularly those that could lead to a change in the prime-ministership, are politically significant events. From the perspective of this article, the question is: how do journalists frame these stories? If, as the initial hypothesis is confirmed and the Press Gallery does act as a pack, it would be anticipated that such stories tend to be covered in similar ways, irrespective of which media organisation the journalist worked for. 
Alternatively, if the party, in this case the government, is in damage control and wants to minimise the fall-out, the likelihood is that much of the information will be provided by the key players (ministers, their advisers, and party powerbrokers) on the understanding that their identity remains a secret. Such an approach points to the reality of politics: politicians will often hedge their bets, particularly in the public arena, so as to minimise the party-political repercussions of a decision to side with one combatant over the other. The sources are likely to undertake a cost-benefit analysis of the consequences of being identified with the release of particular information before sharing their views with journalists. They are also likely to be selective when talking to journalists, identifying those they believe are supportive or at least fair when considering who to talk to and who to ignore. This approach potentially undermines claims that a pack operates whenever the press gallery is pursuing a major story. Against this, however, it may be argued that even though the journalists are working independently on the story, the fact that there are a limited number of knowledgeable sources who can provide them with useful information may also contribute to the working of a pack mentality, albeit at a more clandestine level where the same information is released, but in the first instance to a smaller group of sources. If they are confident as to the veracity of the information and release it under their bylines, chances are it will be picked up by other journalists who are not operating in the same loop.

With a story involving a potential change of leadership, the media can potentially use a number of frames. These may include, but are not limited to, frames which: 1 . focus on the suitability (qualifications, skills, moral standing etc) of the various candidates; 2 . the reasons for the leadership clash; 3 . the potential outcomes of such a challenge; and 4. the merits thereof. There is also likely to be an overlap between frames. Further, the use of frames may change as the issue develops.

While it was tempting to conduct a full-blown analysis of newspapers, radio, television and the internet, given the short time frame involved, it was decided to focus on just two newspapers, both recognised as opinion leaders: The Australian and The Sydney Morning Herald (SMH). These newspapers were selected for a number of reasons. Both are broadsheets and publish Monday to Saturday. The Australian is a national newspaper; The Sydney Morning Herald, while New South Wales-based, also has reasonable circulation outside of its primary distribution area. Both have a strong mix of news and commentary. 
The study begins on Monday, 10 September 2007 and concludes the following Monday, September 17. While in some respects these are arbitrary start and finish dates, they do make sense in the context of how the event developed in the post Asia-Pacific Economic Cooperation (APEC) environment that had dominated Australian political discussions for the previous fortnight. Even though the internal party machinations had begun earlier the previous week, the discussions were kept under wraps during APEC week. By the Sunday night, September 9, most of the APEC leaders had departed Australia, leaving Howard free to consider how he would deal with the perceived threat from within. September 17 was selected as the end point because by that stage the party had essentially resolved the issue. It had decided to rally behind Howard, although in the process had promoted Costello to the almost unenviable position of co-leader.

\section{Table 1: Articles published by date}

\begin{tabular}{|l|c|c|c|c|c|c|c|c|}
\hline & $10 / 09$ & $11 / 09$ & $12 / 09$ & $13 / 09$ & $14 / 09$ & $15 / 09$ & $16 / 09$ & $17 / 09$ \\
\hline SMH & 3 & 4 & 4 & 4 & 6 & 7 & - & 2 \\
\hline $\begin{array}{l}\text { The } \\
\text { Australian }\end{array}$ & 7 & 9 & 10 & 9 & 9 & 10 & - & 5 \\
\hline Total & 10 & 13 & 14 & 13 & 15 & 17 & - & 7 \\
\hline
\end{tabular}

Note: The absence of articles on September 16 reflects the fact that The Australian publishes a weekend edition which is available on the Saturday. The Sydney Morning Herald does not publish on a Sunday. While its parent, Fairfax, publishes a separate newspaper, the Sun Herald, it was decided not to include it in the survey as it has a separate editorial team. Further, including content collected on a Saturday and published on Sunday would potentially have advantaged SMH journalists over their News Ltd colleagues.

\section{Analysis}

As Table 1 reveals, the two newspapers published 89 articles, editorials and cartoons over the eight days that dealt specifically or primarily with this topic. Articles that mentioned the prospect of a challenge in passing were not included in the study. The SMH published 30 articles and The Australian 59, a ratio of almost 2:1 in favour of The Australian. As with most issues, it is possible to chart the media's interest by a simple number count of articles published on a daily basis. The $S M H$ 's coverage was relatively consistent over the first four days, increasing on days five and six before dropping off on day eight. The Australian's coverage was even more consistent over days 
one to six. After publishing seven stories on day one, its coverage ranged between nine and 10 stories over each of the following five days before dropping to five on day eight.

The articles were broken down into four categories: news, opinion (including analysis and background), editorials and cartoons (Table 2). The Australian out-numbered the $S M H$ in three of the four categories (news, opinion and cartoons). Interestingly, the $S M H$ published double the number of editorials (four to two). They made the same use of in-story cartoons (two apiece, although the Australian also embedded small, single column cartoons among letters to the editor (two). The highly sensitive nature of this story was confirmed early on when journalists were forced to conceal the identity of most sources (albeit known to them) to provide the background required to piece together the events. For example, it was noticeable - and highlighted by journalists - that few ministers were prepared to be named, or to openly comment on the prospect of a challenge, or even its likely outcome. The two early exceptions were the Prime Minister and Alexander Downer, the Minister for Foreign Affairs. Downer was the man entrusted by the Prime Minister with the task of sounding out his colleagues on their attitudes towards change. Both newspapers also highlighted the fact that Costello, as the man most likely to succeed Howard in the event of a challenge, would not speak to journalists, a strategy that served to further fan speculation about the level of disharmony within Liberal ranks and the prospect of a challenge. It was not until after the Prime Minister had dimissed talk of resignation, and said that those who supported his replacement would not be treated as traitors, that others ministers agreed to go on the record.

Table 2: Breakdown of articles by category

\begin{tabular}{|l|c|c|c|c|}
\hline & News & $\begin{array}{c}\text { Opinion/ } \\
\text { analysis/ } \\
\text { background }\end{array}$ & Editorial & Cartoons \\
\hline SMH & 11 & 12 & 4 & $6^{*}$ \\
\hline Australian & 16 & 31 & 2 & $15^{*}$ \\
\hline Total & 27 & 43 & 6 & 21 \\
\hline
\end{tabular}

*Note: A number of these are in-story cartoons, rather than stand-alone commentaries published on the opinion pages. This also explains why the totals in Table 1 do not match those in Table 2. 


\section{Table 3: Confirming source credibility}

\begin{tabular}{|c|c|}
\hline$S M H$ & $\begin{array}{l}\text { 'senior coalition sources' } \\
\text { 'an unaligned senior minister' } \\
\text { 'senior people within the party' } \\
\text { 'said one confidant' } \\
\text { 'one senior minister who said that ...' } \\
\text { 'a source close to Peter Costello said ...' } \\
\text { 'Senior ministers agreed ...' } \\
\text { 'one minister who did not want to be identified ...' } \\
\text { 'one senior backbencher and a Howard loyalist ...' }\end{array}$ \\
\hline $\begin{array}{l}\text { The } \\
\text { Australian }\end{array}$ & $\begin{array}{l}\text { 'senior Liberals ...' } \\
\text { 'Liberal ministers are convinced that ...' } \\
\text { 'ministers and backbenchers killed off speculation that ...' } \\
\text { 'two frontbenchers ...' } \\
\text { 'the senior frontbencher said ...' } \\
\text { 'emails from Howard supporters who said ...' } \\
\text { 'senior ministers have advised ...' } \\
\text { 'even Howard's staunchest Cabinet supporters concede privately ...' }\end{array}$ \\
\hline
\end{tabular}

Importantly, while the journalists did not name sources, they did go out of their way to give readers the impression that they were reputable, as the phrases in Table 3 reveal. The use of such phrases or word combinations reinforces the arguments of Druckman and Lupia (above) regarding the importance of source credibility. By using these phrases, the journalists are clearly indicating to readers that the information upon which they are basing their stories is authoritative. However there were a small number of exchanges during the course of the crisis which suggested that some sources were not being entirely open with journalists, including comments on television by Alexander Downer regarding the degree of support within cabinet early on for the proposition that Howard should stand aside. While discredited by subsequent accounts of the meeting between Downer and other senior ministers at which Howard's fate was openly discussed, this early exchange did highlight the vulnerability of journalistseven experienced ones-to political spin.

This was also confirmed by the fact that journalists were often required to deal with second-hand information. For example at one stage it was alleged that information had been leaked to Sky News in a deliberate attempt to discredit Howard. This was apparently a response by disgruntled 
ministers to the fact that Howard - as the architect of the Quay Grand meeting to assess the level of support he retained-then refused to accept the recommendations of those he asked to be canvassed, preferring to accept instead the advice of his family to stand firm and fight on. The journalists willingly picked up on this information, as they did Howard's forays into commercial radio and $\mathrm{ABC}$ television to help shore up his position. Costello, for his part, held just one press conference-after the much anticipated party room meeting on September 12. While he willingly embraced and talked about his joint leadership role from that point onwards, he had been noticeably quiet in the days leading up to the re-endorsement of Howard, a factor which did not escape the attention of senior journalists.

From an organisational perspective, the media were also saying to readers that by assigning senior journalists to cover the story they were taking it seriously and readers should do the same. The key writers involved in the reporting on this issue from the two newspapers are identified in Table 4.

A number of other people received bylines for stories or opinion pieces on this issue, including staff journalists, commentators and cartoonists, as well as non-staff contributors (including former members of Parliament, staffers, or politically aligned individuals) Some stories also canvassed the opinions of academics and pundits). The mix of stories provided by the journalists identified above ranged from the serious to the somewhat humorous. In the latter category were the contributions of Price (The Australian) and Crabb (the $S M H$ ). Both were recognised as senior writers, even though their bylines did not carry such a designation. The fact that both newspapers saw it

Table 4: Designation of key journalists covering story

\begin{tabular}{|l|l|l|}
\hline Publication & Name & Job designation \\
\hline \multirow{3}{*}{ Sydney Morning Herald } & Phillip Coorey & Chief political correspondent \\
& Peter Hartcher & Political editor \\
& Annabel Crabb & Not provided \\
\hline & Dennis Shanahan & Political editor \\
& Patricia Karvelas & Political correspondent \\
& Matthew Franklin & Chief political correspondent \\
& Paul Kelly & Editor-at-large \\
& Mike Steketee & National affairs editor \\
& Jennifer Hewett & National affairs correspondent \\
& Matt Price & Not provided \\
\hline
\end{tabular}


appropriate to publish humorous pieces should not be seen as an attempt to diminish the importance of the issue, but rather a reflection on the journalists' interpretation of the wisdom behind the manoeuvrings (a theme that was also picked up in cartoons and even more serious comment pieces).

Having established the seriousness with which the journalists and newspapers attached to the issue, the paper now turns to the key frames employed in presenting it. The key frames were built around the following themes :

1. The prospect of a possible challenge to Prime Minister Howard's leadership; and

2. Potential outcomes (to the Prime Minister, Costello and even the party) in the event of the challenge being successful or unsuccessful.

These frames are very broad and do not take into account the subtleties of the issue. Because of that it is important to dig deeper, a process which identifies a number of sub-frames (or themes) that help to explain the attitudes of journalists to the issue and even their interpretation thereof.

\section{Frame 1: The prospect of a challenge.}

Despite the excitement that the prospect of a leadership challenge traditionally generates within the federal parliamentary press gallery, on this occasion the media's reaction was, on the whole, relatively measured. In fact, there was little evidence of a 'feeding frenzy', either in terms of the journalists' reaction to the story, or the language they adopted when writing about it. In fact there were only three references that supported such an interpretation. In one Australian article, the reporter referred to the 'media maelstrom', another highlighted the 'frenzied speculation within the Canberra Press Gallery'. The third was a more measured response by former Labor opposition leader Kim Beazley who was quoted in the $S M H$ as likening the Press Gallery to 'three rows of crows, waiting for the sheep to die. Yum, yum'.

Journalists in a feeding frenzy could generally be expected to provoke the challenge, perhaps even goad Costello or his supporters into mounting it, perhaps by indicating that such a challenge could help the government's chances of retaining office. However in this case the journalists did the 
opposite. There was no noticeable support among either The Australian or Sydney Morning Herald journalists for the challenge. In fact they stated without exception that any challenge, if it were to eventuate, was six to 12 months too late. The only support for change came from a senior television journalist in his weekly column in The Australian and by a young, conservative non-journalist commentator published in the same paper.

Journalists were agreed that: 1 . a change of leadership only months out from an election campaign would paint the impression that the government was panicked by the succession of public opinion polls which showed the gap between it and the Opposition led by Kevin Rudd increasing; 2. John Howard had the tenacity required to reduce the gap between the Liberals and Labor in the opinion polls; and 3. if Peter Costello were successful in toppling Howard, he would not have sufficient time to establish his credentials as leader and Prime Minister.

Not surprisingly, journalists' early attention was focused on a small number of bread-and-butter questions: 1. who was behind the challenge? 2. would it succeed? Early speculation was that the challenge was being led by Peter Costello, supported by the Environment Minister Malcolm Turnbull, and another Minister, Mal Brough. However journalists were surprised to hear that the prospect of a challenge had in fact resulted from a prime ministerial edict to Alexander Downer that he canvass the level of support for Howard among ministers. This question was posed at a post APEC meeting attended by nine ministers in Downer's suite in the Quay Grand Hotel in Sydney. Highlighting the strength of their relationship with ministers, senior journalists were able to outline in detail the conversations that took place in the room and the conclusions reached, including the view that Howard should step down in favour of Costello.

However, rather than provoke a feeding frenzy among journalists, this actually produced a collective 'wise head' approach. Not only did the journalists dismiss the wisdom of an 11th hour change of leader, but wrote about the coalition's reaction in the following terms (see Table 5).

\section{Frame 2: The outcomes of a challenge.}

As journalists pointed out, a change in leadership at this late stage would not only play into Labor's hands, but also send the wrong message to voters. Journalists argued that while the government was unlikely to win the 
Table 5: Language describing coallition response to issue

\begin{tabular}{|c|c|}
\hline Sydney Morning Herald & The Australian \\
\hline $\begin{array}{l}\text { [Members of the Coalition resembled] } \\
\text { 'chooks running around with their heads } \\
\text { cut off'. } \\
\text { Government was described as being 'in } \\
\text { a funk' } \\
\text { 'paralysed, and the ministry divided'. } \\
\text { 'crisis of confidence.' } \\
\text { 'paralysis of the party'. } \\
\text { 'unrest'. } \\
\text { 'it would rightly be accused of panicking'. } \\
\text { 'panicked speculation in the Party.' } \\
\text { 'damaging display of Cabinet disunity.' }\end{array}$ & $\begin{array}{l}\text { 'panic and disarray, } \\
\text { 'convulsed by leadership confusion' } \\
\text { 'political suicide' } \\
\text { 'rattled' } \\
\text { 'confusion and pessimism' } \\
\text { 'anger' } \\
\text { [MPs were] 'perplexed' }\end{array}$ \\
\hline
\end{tabular}

election, it could not be completely written off. In taking this approach, journalists pointed to Howard's record as Prime Minister, particularly the fighting qualities that he showed during elections and when under challenge, as at present. The descriptors used to profile the Prime Minister are outlined in Table 6.

These descriptors paint an interesting portrait of Howard, and the likelihood that he would fight to retain his position. On the other hand, there are signs of a developing character flaw that ultimately would undermine his aspirations.

While Costello certainly elicited some support from journalists for his performance as Treasurer, there were doubts that he would be able to make the transition to the prime ministership in the time available. As such, any change was widely seen as a 'poisoned chalice'. In the eyes of journalists, Costello carried considerable baggage which undermined his chances of leading the Coalition to victory without a reasonable lead-time in which to establish his credentials and popular appeal. For example, journalists pointed to the fact that on this occasion Costello was reluctant to challenge for the leadership, preferring to be drafted into the position. This was seen as arrogance on his part. Another weakness was the fact that at no time had he openly challenged for the leadership; he had made regular mutterings about a challenge in discussions with journalists, but the words had never translated into action. Finally, he was widely regarded by journalists-confirmed by the opinion 
Table 6: Howard's character defined

\begin{tabular}{|c|c|}
\hline Sydney Morning Herald & The Australian \\
\hline $\begin{array}{l}\text { 'hanging as if life itself depended on it' } \\
\text { 'made it plain it was too late for him to } \\
\text { bail out now.' } \\
\text { 'defiant' } \\
\text { 'unable to bring himself to contemplate } \\
\text { a graceful exit'. } \\
\text { 'John Howard clung doggedly to his } \\
\text { leadership yesterday'. } \\
\text { [the PM had]' 'thrown down the gaunt- } \\
\text { let' } \\
\text { 'a serious lapse of judgment [on the } \\
\text { PM's part]' } \\
\text { 'irony is that much of the turmoil is of } \\
\text { the PM's own making'. }\end{array}$ & $\begin{array}{l}\text { 'Referred to the 'PM's thick skin' } \\
\text { PM's 'thick hide' } \\
\text { 'unbowed' } \\
\text { 'waffling, defensive and almost pleading' } \\
\text { 'transfixed [by the opinion polls]' } \\
\text { 'doesn't have the steel in him to win this } \\
\text { time'. } \\
\text { 'we'll all go down with him' } \\
\text { 'rattled [by poll results]' } \\
\text { 'stared down nervous colleagues' } \\
\text { 'I have never run from a fight and I don't } \\
\text { intend to do so now.' } \\
\text { Refusal to resign described as 'a firm } \\
\text { and visceral reaction'. } \\
\text { 'Howard's will is prevailing'. }\end{array}$ \\
\hline
\end{tabular}

polls-as less popular than Howard, despite the fact that he was almost 20 years younger (in fact was a similar age to that of Labor challenger Kevin Rudd), and he was seen as one of the architects of the government's policies. Accordingly, journalists did not believe the government's chances of winning under Costello would be enhanced if he were thrust into the leadership at such a late stage.

In looking at the possible outcomes, the journalists devoted considerable space to the government's strategy of elevating Costello to joint leadership of the party to help boost the party's claims that it not only had a plan for the future, but had put in place the mechanism that would enable a smooth transition from Howard to Costello to take effect. The proposal met with mixed reviews from journalists, commentators and cartoonists. One cartoonist, for example, saw it as a handicap and presented the new leadership team as running in a three legged race against a man who had already burst out of the blocks and was well down the track while Howard and Costello were still being tied together. Some journalists and commentators saw merit in the proposal, while others believed that it was a band-aid solution that would not win back the support of voters who had abandoned the government.

Linked to this was another concern highlighted by journalists, and in editorials as well, namely whether the government had the capacity to address 
one of the major criticisms that had been directed at it: its tendency to focus on the past and the present while ignoring the future. Howard acknowledged this and said it was one of the government's priorities in the lead-up to the election, an announcement Costello took a cue from to say that he would be taking a proactive role in policy areas outside his traditional ministerial responsibilities. While there was some suggestion, particularly in editorials, that the government had the capacity to claw back Labor's lead in the polls before the election if it showed evidence of self-renewal, the majority of journalists considered this to be well nigh impossible, given what they rightly, in hindsight, perceived to be a mood for change.

At the end of the day, however, the journalists kept returning to one key theme: Howard did not know when to retire. In considering this issue, journalists used recent history to draw comparisons between Howard's intransigence and other leaders who had known when to retire, including former British Prime Minister Tony Blair, and Australian state Labor leaders, including Geoff Gallop, Bob Carr, Steve Bracks and Peter Beattie, who had somewhat pointedly announced his retirement as Queensland Premier after 10 years while the federal Liberal leadership crisis was unfolding. Howard's attempts at justifying his decision to hold on to power were painted as selfish by journalists.

\section{Discussion}

Research shows that media organisations - and the journalists they employ - have considerable capacity to shape the way in which audiences respond to issues. The purpose of this article was to test that hypothesis on two inter-linked levels. The first was to provide some insight into whether the Australian federal press gallery works as a pack in dealing with an important political issue: namely an anticipated leadership clash between the Prime Minister and Treasurer in late 2007. The second was to see whether there is any evidence that journalists working in a pack environment use similar frames when reporting or commenting on a potentially important issue such as this.

The article suggests there is some evidence to support the contention that the pack operates even when political sources conspire to keep journalists separate (that is, by talking to journalists one on one, rather than in a press conference situation, or even by making comments through a limited range 
of media outlets which has the effect of forcing journalists to run with 'what they can pick up' on a second-hand basis rather than having direct access to the sources themselves). Clearly the tactics adopted by politicians and their advisers can have a clear impact on the way in which an issue is managed and, potentially, even presented to the public.

While the study was restricted to a small sample of articles published in just two newspapers, it nonetheless supports the contention that journalists are likely to adopt similar frames when covering predictable stories. Without conducting interviews with the journalists involved, it is impossible to state categorically why this is the case. However, it is possible to posit a number of suggestions that are worthy of further analysis. Firstly, the journalists read and listen to each other. Because of this, it is likely that they will be influenced by and react to the writings of other members of the pack. As such, even if the pack is tactically split because of the way in which the issue is managed politically, there will still be interaction at an intellectual level. Secondly, the nature of journalism is such that other factors, including news values, will influence the way in which material is reported.

Finally, the media's coverage of this issue points to the existence of an element of responsible journalism among members of the Canberra Press Gallery. It could have been very tempting to goad the would-be challenger into action. Instead, the 'wise heads' in the Gallery counseled against such an action and in so doing spared the Liberal Party considerably more anguish and-ultimately - embarrassment. As such, the framing of this issue in a measured way may have rubbed off on the political actors while at the same time still providing readers with an understanding of the pros and cons of the leadership stoush as well as an insight into political motives.

\section{References}

Druckman, J.N. (2001). On the limits of framing effects: Who can frame? Journal of Politics 63(4), 1041-66.

Economou, N., \& Tanner, S.J. (2008, forthcoming). Media, politics and power. French's Forest: Pearson Longman.

Goffman, E. (1974). Frame analysis: An essay on the organization of experience. New York: Harper and Row.

Lupia, A. (2001). Who can persuade whom? Implications from the nexus of psychology and rational choice theory. In James H. Kukinski (Ed.), Political psychology. New York: Cambridge University Press. 
McCombs, M. (2005). A look at agenda-setting: Past, present and future. Journalism Studies, 6(4), 543-57.

McCombs, M., \& Ghanem, S. (2001). The convergence of agenda setting and framing. In Reese, S.D., Gandy, O.H., Jr, \& Grant, A.E. (Eds.), Framing public life: Perspectives on media and our understanding of the social world. Mahwah, NJ: Lawrence Erlbaum Associates.

Nelson, T.E., \& Oxley, Z.M. (1999). Issue framing effects and belief importance and opinion. Journal of Politics, 61(4), 1040-67.

Richardson, N. (2002). Playing political games: Ministers, minders and information. In Tanner, S.J. (Ed.), Journalism: Investigation and research (pp. 170-83). Frenchs Forest: Longman.

Sabato, L. (1991). Feeding frenzy: How attack journalism has transformed American politics. New York: Free Press.

Simons, M. (1999). Fit to print: Inside the Canberra press gallery. Sydney: UNSW Press.

Tankard, J.W. (2001). The empirical approach to the study of media framing. In Reese, S.D., Gandy, O.H., Jr, \& Grant, A.E., (Eds.), Framing public life: Perspectives on media and our understanding of the social world. Mahwah, NJ: Lawrence Erlbaum Associates.

Tankard, J.W., Hendrickson, L., Silberman, J., Bliss, K., \& Ghanem, S. (1991, August). Media frames: Approaches to conceptualization and measurement. Paper presented to the Association for Education to Journalism and Mass Communication, Boston.

Tanner, S.J. (1999). Political corruption, accountability and the media. Unpublished doctoral thesis, University of Tasmania.

Tanner, S.J., Phillips, G., Smyth, C., \& Tapsall, S. (2005). Journalism ethics at work. Frenchs Forest: Pearson Longman.

Tiffen, R. (1989). News and power. Sydney: Allen and Unwin.

Tuchman, G. (1978). Making news: A study in the construction of reality. New York: Free Press.

Ward, I. (1995). Politics of the media. South Melbourne: Macmillan.

White, D.M. (1950). The gatekeeper: A case study in the selection of news. Journalism Quarterly, 27, 383-96.

Wilmoth, P. (1994, May 22). The Pack, Sunday Age, Agenda 3.

Dr Stephen Tanner is associate professor and head of the School of Journalism and Creative Writing at the University of Wollongong. He would like to thank the reviewers for their constructive comments. stanner@uow.edu.au 